columns

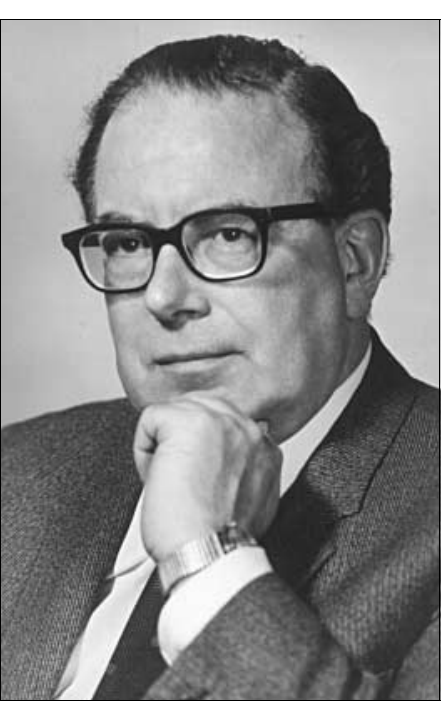

\section{Max Berthold Clyne}

Formerly General Practitioner, Southall, Middlesex

Dr Clyne was born in Leipzig, Germany, in 1910 and came to England in 1936. As his degree was not recognised, he initially worked as a pharmaceutical representative, but following naturalisation, he was commissioned into the Indian Medical Service in 1940 and served in India until he was demobbed in 1946. On returning to civilian life in England, he worked as a locum in London until he became a partner in a general practice in Southall in 1947, where he remained until retirement. He belonged to the Royal Army Medical Corps of the Army Emergency Reserve and was called up for the Suez emergency, retiring with the rank of Lieutenant Colonel when the Reserve was reorganised in 1961.

His introduction to psychiatry happened in 1951 when, in his search for an understanding of 'neurotic' patients, he made contact with the Tavistock Clinic, London. Following correspondence with the then Director, Dr John (Jock) Sutherland, he was invited to attend lectures by two psychiatrists, Drs Dicks and Luff. This led him to join the first discussion group on psychological problems in general practice given by $\mathrm{Dr}$ Dicks, together with a $\mathrm{Dr}$ Michael Balint, in April 1951.

The few general practitioners in this group were in awe of these men, who were not just psychiatrists, but were also psychoanalysts. However, this was the beginning of his fascination with psychiatry and Balint groups, with which he was involved until his retirement in 1990. These doctors at the 1951 meeting formed the first Balint group, and by the time of Balint's death, in 1970, about 300 doctors had gone through training in such groups. Following Balint's death, the Balint Society of Great Britain was formed and Dr Clyne was President from 1974 to 1976

A number of publications, both by Balint and members of this group emanated from their early work. His own publications included two books: Night Calls (1961) and Absent: School Refusal as an Expression of Disturbed Family Relationships (1964). In addition he published over 70 articles, in British and foreign medical journals, on the application of psychiatric and psychotherapeutic thought in general medicine.

He successfully combined his interest in psychiatry with his main field of general practice. He was a founding member of the (Royal) College of General Practitioners, was awarded the James Mackenzie Prize in 1967 and obtained Fellowship in 1969. He was a clinical assistant in group psychotherapy at St Bernard's Hospital, Southall (1963-1975) and at Wembley Hospital (1966-1973). In 1975 he was a member of a joint Royal College of General Practitioners' and Royal College of Psychiatrists' Working Party considering the training of general practitioners in psychiatry. He was also a member of Council of the Royal College of Psychiatrists from 1976 to 1979 and was awarded a Fellowship in 1986.

In his final few years he suffered increasing physical and mental frailty, having to reside in a nursing home for the last 2 and a half years. He died on 24 January, 2000. Predeceased by his wife, he leaves a son (a doctor, myself) and twin grandsons.

\section{References}

CLYNE, M. B. (1961) Night Calls. London: Tavistock Publications.

- (1964) Absent: School Refusal as an Expression of Disturbed Family Relationships. London: Tavistock Publications.

\section{Michael J. Clyne}

\section{Tom Pitt-Aikens}

\section{Formerly Consultant Psychiatrist, Cassel Hospital, Surrey}

Dr Tom Pitt-Aikens died on 16 May 1999 after a long fight against cancer at the early age of 59 years. He was a child and adolescent psychiatrist and psychoanalyst who specialised in the causes and treatment of delinquency in young people. He became a recognised authority in this field in London and the Home Counties where he worked. He was also more widely known because of his writings, especially two books he wrote in collaboration with the novelist Alice Thomas Ellis, Secrets of Strangers and Loss of the Good Authority. He graduated from Bristol in 1963 and entered psychiatry 4 years later. He was elected a Fellow of the Royal College of Psychiatrists in 1984 and Associate Member of the British Psychoanalytical Society in 1976. He was a consultant at the Cassel Hospital, Finnart House, Stamford House and the Feltham Borstal, as well as having a private psychoanalytic practice.

He conceived of 'the good authority', a complex benign presence in families, institutions and other organisations, whose understandings and controls encompass the lives and awareness (both conscious and unconscious) of their members. The good authority shields them from the tendency of historical and contemporary family and other pressures to distort or limit self-perception and behaviour. Its absence or loss, which is invariable in delinquency, he believed to be the underlying cause of antisocial behaviour, and his treatments attempted to re-establish this integrative presence in the families and close associations of his patients. He used group methods, which included the child's social worker as his primary client, and an agreed 'focus' rather than an individual as a reference point. He also did individual and marital therapy with the child's parents, and individual work with the child. With the same aim he worked with groups of young offenders and in institutions of various kinds dealing with them. In this work he was flexible, imaginative and effective.

His awareness of the possibility of losing this sense of an accompanying good and saving presence may have arisen in part from the many moves he experienced during his school years. In his own family though, he was clearly experienced as the embodiment of his ideal, its mainstay after his father's death, despite

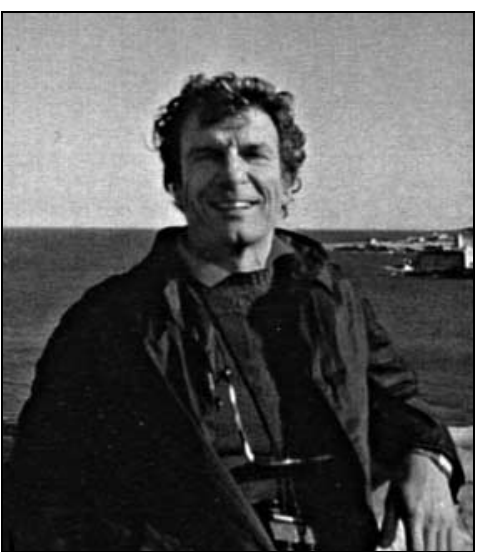

